Available online on 15.02 .2020 at http://ajprd.com
(c) 2013-20, publisher and licensee AJPRD, This is an Open Access article which permits unrestricted non-
commercial use, provided the original work is properly cited

Open $\odot$ Access

Research Article

\title{
Formulation and In-Vitro Evaluation Curcumin Ovule with Polyethylene Glycol (Peg) Base
}

\author{
Dathin Aulia Delarosa1 *, Sumaiyah S1, Poppy Anjelisa Z. Hasibuan² \\ ${ }^{1}$ Department of Pharmaceutical Technology, Faculty of Pharmacy, Universitas Sumatera Utara, \\ Medan, Indonesia \\ ${ }^{2}$ Department of Pharmacology, Faculty of Pharmacy, Universitas Sumatera Utara, Medan, Indonesia
}

\section{A B S T R A C T}

Objective: This study aims to formulate and in vitro evaluation curcumin ovule with polyethylene glycol bases 400 and 6000 concentration variation using fushion method.

Method: Curcumin ovule formulated by fushion method using the comparison of polyethylene glycol 400 and 6000 base concentration. In vitro evaluation of preparations included observation of organoleptic (odor, color, and shape), measurement of uniformity of weight, disintegration time, observation of stability of the preparation during 6 months storage at refrigerator temperature, and release test.

Results: The results showed that all preparations ovule curcumin were orange, specific odor, cone-shape, stable for 6 months storage at refrigerator. Uniformity of ovule weight and disintegration time according the standard prepaation. Ovule release test showed formula I polyethylen glycol base concentration of $400(90 \%)$ and $6000(10 \%)$ very fast to release of curcumin from the preparation compared to other formula is gave average release of $93,7 \% \pm$ SD 0.36 .

Conclusion: Curcumin can be formulated in the form of ovule using polyethylene glycol bases 400 and 6000 concentration variation.

Key Words: Curcumin, polyethylene glycol, disintegration time.

\begin{tabular}{l}
\hline A R T I C L E I N F O: Received 25 Nov 2019; Review Completed 13 Jan 2020; Accepted 25 Jan 2020; Available online 15 Feb. 2020 \\
Cite this article as: \\
Delarosa DA*, Sumaiyah S, Hasibuan PAJ, Formulation and In-Vitro Evaluation Curcumin Ovule with Polyethylene Glycol \\
Dil/dx.doi.org/10.22270/ajprd.v8i1.650
\end{tabular}

\section{INTRODUCTION}

$\mathrm{T}$ he development of pharmaceuticals in the field of pharmaceutical technology is increasingly rapid. The basis for consideration in the development of technology consists of three main factors, namely effectiveness, safety, and acceptable ${ }^{8}$. Technologically, it has long been developed for vaginal suppositories. So there are opportunities to develop preparations the aimed at local and systemic treatment. Vaginal suppositories are solid preparations used through the vagina, generally oval-shaped, can dissolve, soften, and melt at body temperature. Overall permeability of the vaginal epithelium to various penetrants is greater than the rectal, buccal, or transdermal route ${ }^{2}$. Ovule forming agents are preferably water soluble to minimize the melting of the oil. Curcumin is a natural phenolic antioxidant, yellow, not soluble in water but soluble in ethanol, dimethyl sulfoxide and acetone, and has many benefits that have been studied. Generally, curcumin is isolated from tumeric. There are consists of $80 \%$ curcuminoid complex, demethoxycurcumin(17\%), and bisdemethoxicurcumin (3\%). Curcumin(1,7-bis (4-hydroxy-3-methoxyphenyl) 1,6-heptadiene-3,5-dione) as a Generally Recognized as Safe (GRAS) / is recognized as safe by the Food and Drug Administration (FDA) ${ }^{3}$. In spectrophotometry curcumin has maximal absorbance at a wavelength of $430 \mathrm{~nm}$ which follows the Lambert-Beer law in a concentration range of 0.5 to $5 \mu \mathrm{g} / \mathrm{mL}$.chemicalstructur of curcumin can be seen in Fig.1.<smiles>COc1cc(/C=C/C(=O)/C=C(O)/C=C/c2ccc(O)c(OC)c2)ccc1O</smiles>

Figure 1: Chemical structur of curcumin 
Curcumin is stable under acid conditions, unstable under alkaline conditions, temperature, and the light. The acid curcumin is yellow to orange, while in the alkaline conditions is red. This can happen because of the tautometry system in the molecule ${ }^{11}$.

PEG mixture can be used as a base of ovules. The mixing polymers according to certain compositions a melting temperature is need. High polymers produce crushed products and release the drug slowly. Softer masses produce brittle, fragile preparations. Faster drug release is obtained by mixing high molecular weight PEG with low molecular polymer ${ }^{2}$.Polyethylene glycol (PEG) is available in several molecular weights from 200 to tens of thousands. At the room temperature, PEG is water soluble and hygroscopic. PEG in the colorless viscous liquid form having a molecular weight of $<600$ and a waxy white solid form having a molecular weight of $>800^{4}$. PEG is included in the FDA's GRAS list, (compound Generally Recougnized as Safe) and has been approved by the FDA and can be consumed ${ }^{6}$.

\section{MATERIAL AND METHODS}

\section{Materials}

Curcumin(Tokyo Chemical Industry Co., Ltd.), PEG 400, PEG 6000, citrate buffer, and ethanol. All other chemical were of analytical grade.

\section{Apparatus and conditions}

Spechtrophotometry Uv-Vis (Shimadzu Uv-Vis 1800), dissolution apparatus II (copley), desintegration tester (copley), stopwatch, and ovule mold.

\section{Curcumin calibration curve testing}

Curcumin standard solution was made to $0.4 ; 0.8 ; 1.2 ; 1.6$; and $2 \mathrm{ppm}$ concentration. Uptake was measured bgUv-Vis spectrophotometry at a waveleght of $430 \mathrm{~nm}$.

\section{Formulation of curcumin ovule}

Ovules made by 3 grams. The concentration of each formula is listed in Table 1.

Table 1: Formulas curcumin ovule

\begin{tabular}{|c|c|c|}
\hline Formula & $\begin{array}{l}\text { Curcumin } \\
\text { concentration }\end{array}$ & $\begin{array}{l}\text { Ovule base } \\
\text { PEG } 400 \text { : PEG } 6000\end{array}$ \\
\hline 1 & \multirow{9}{*}{$5 \%$} & $10: 90$ \\
\hline 2 & & $20: 80$ \\
\hline 3 & & $30: 70$ \\
\hline 4 & & $40: 60$ \\
\hline 5 & & $50: 50$ \\
\hline 6 & & $60: 60$ \\
\hline 7 & & $70: 30$ \\
\hline 8 & & $80: 20$ \\
\hline 9 & & $90: 10$ \\
\hline
\end{tabular}

Made by the fusion method. The base of the ovule is melted at $37^{\circ} \mathrm{C}$, then curcumin is added and stir until homogeneous. The mass is poured into the ovule mold ${ }^{1}$.

\section{Ovule evaluation}

\section{Organoleptic test}

Ovule observations include odor, color, and shape.

\section{Uniformity of weight}

Testing is weighing each of the 20 ovules, then weighing together 20 of these ovules. Calculated average weight. The conditions is no more 2 ovules than $5 \%$ of the average weight, and no ovule more than $10 \%$ of the average weight ${ }^{5}$.

\section{Disintegration time}

The using disintegration tester with media citrate buffer $\mathrm{pH} 4.5$ at $37^{\circ} \mathrm{C}$. disintegration time is the time it takes for the ovules to melt completely in the media.

\section{Stability}

Stability test during 6 months storage at refrigerator temperature include ovule observations odor, color, and shape.

\section{Release test}

The tested using dissolution apparatus II (paddle model). The paddle rotates at $50 \mathrm{rpm}$ in $900 \mathrm{ml}$ citrate buffer $\mathrm{pH}$ 4.5 (vaginal $\mathrm{pH}$ model) at $37^{\circ} \mathrm{C} \pm 0.5^{\circ} \mathrm{C}$. Each time interval, a sampel of $5 \mathrm{ml}$ is taken from the dissolution medium and replaced with a new medium. The sample taken was diluted in a $25 \mathrm{ml} \mathrm{flask,} \mathrm{then} \mathrm{analyzed} \mathrm{at} \mathrm{a}$ waveleght of $430 \mathrm{~nm}^{7.10}$. each treatments was repeated three times.

\section{RESULT AND DISCUSSION}

\section{The results of the curcumin calibration curve}

Curcumin calibration curve can be seen in Fig.2. The graph shows the absorbance vs concentration of curcumin obtained by regression $\mathrm{Y}=0.023 \mathrm{X}+0.001$ and $\mathrm{r}$ value is 0.998 .

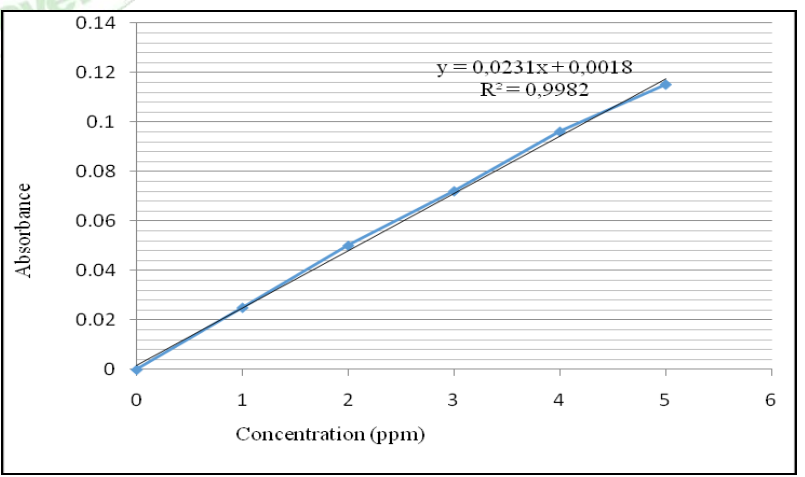

Figure 2: Curcumin calibration curve

\section{Ovule preparations}

Ovule preparations in the form of orange solid. Ovule length $4 \mathrm{~cm}$ with a diameter of $4.5 \mathrm{~cm}$ can be seen in Fig.3.

\section{Organoleptic and stability observation}

Evaluations results include the color, odor, and shape of the ovules of each formula for 6 months indicated that curcumin ovule has a good stability for 6 months and can be seen in Table 2 . 


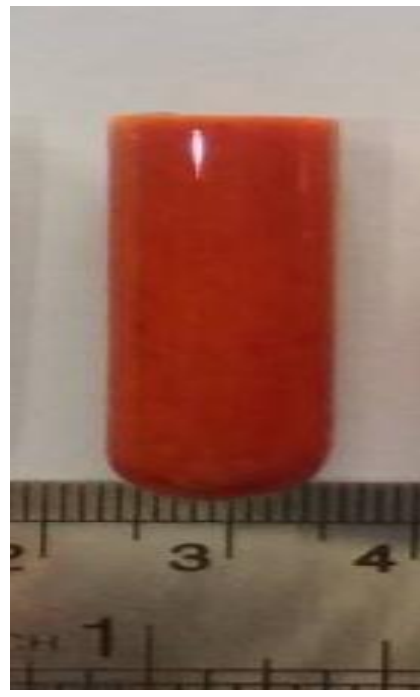

Figure 3: Curcumin ovule

Table 2: Stability results curcumin ovule

\begin{tabular}{|c|c|c|c|c|c|c|c|c|c|}
\hline \multirow[t]{2}{*}{ Formula } & \multicolumn{3}{|c|}{1 months } & \multicolumn{3}{|c|}{3 months } & \multicolumn{3}{|c|}{6 months } \\
\hline & Odor & Color & Shape & Odor & Color & Shape & Odor & Color & Shape \\
\hline 1 & $\mathrm{~S}$ & $\mathrm{O}$ & C-s & $\mathrm{S}$ & $\mathrm{O}$ & C-s & $\mathrm{S}$ & $\mathrm{O}$ & C-s \\
\hline 2 & $\mathrm{~S}$ & $\mathrm{O}$ & C-s & $\mathrm{S}$ & $\mathrm{O}$ & C-s & $\mathrm{S}$ & $\mathrm{O}$ & C-s \\
\hline 3 & $\mathrm{~S}$ & $\mathrm{O}$ & C-s & $\mathrm{S}$ & $\mathrm{O}$ & C-s & $\mathrm{S}$ & $\mathrm{O}$ & C-s \\
\hline 4 & $\mathrm{~S}$ & $\mathrm{O}$ & C-s & $\mathrm{S}$ & $\mathrm{O}$ & C-s & $\mathrm{S}$ & $\mathrm{O}$ & C-s \\
\hline 5 & $\mathrm{~S}$ & $\mathrm{O}$ & C-s & $\mathrm{S}$ & $\mathrm{O}$ & C-s & $\mathrm{S}$ & $\mathrm{O}$ & C-s \\
\hline 6 & $\mathrm{~S}$ & $\mathrm{O}$ & C-s & $\mathrm{S}$ & $\mathrm{O}$ & C-s & $\mathrm{S}$ & $\mathrm{O}$ & C-s \\
\hline 7 & $\mathrm{~S}$ & $\mathrm{O}$ & $\mathrm{C}-\mathrm{s}$ & $\mathrm{S}$ & $\mathrm{O}$ & C-s & $\mathrm{S}$ & $\mathrm{O}$ & C-s \\
\hline 8 & $\mathrm{~S}$ & $\mathrm{O}$ & C-s & $\mathrm{S}$ & $\mathrm{O}$ & C-s & $\mathrm{S}$ & $\mathrm{O}$ & C-s \\
\hline 9 & $\mathrm{~S}$ & $\mathrm{O}$ & C-s & $S$ & $\mathrm{O}$ & C-s & S & $\mathrm{O}$ & C-s \\
\hline
\end{tabular}

\footnotetext{
*S : Specific, O : Orange, C-s : Cone-shape
}

Table 2 shows that the curcumin ovule stored at refrigerator temperature remains clear for up to 6 months. The smell, color and shape are unchanged for each formula.

\section{The results uniformity of weight}

The results of the calculations average uniformity of weight ovule can be seen Table 3.

Table 3: Uniformity weight curcumin ovule

\begin{tabular}{|l|l|l|l|l|l|l|l|l|l|}
\hline Weight (W) & F1 & F2 & F3 & F4 & F5 & F6 & F7 & F8 & F9 \\
\hline $\mathbf{W}_{\text {total }}$ & $62.293 \mathrm{~g}$ & $62.285 \mathrm{~g}$ & $62.318 \mathrm{~g}$ & $62.317 \mathrm{~g}$ & $62.375 \mathrm{~g}$ & $62.291 \mathrm{~g}$ & $61.982 \mathrm{~g}$ & $61.854 \mathrm{~g}$ & $61.594 \mathrm{~g}$ \\
\hline $\mathbf{W}_{\text {average }}$ & $3.114 \mathrm{~g}$ & $3.114 \mathrm{~g}$ & $3.115 \mathrm{~g}$ & $3.115 \mathrm{~g}$ & $3.118 \mathrm{~g}$ & $3.114 \mathrm{~g}$ & $3.099 \mathrm{~g}$ & $3.092 \mathrm{~g}$ & $3.08 \mathrm{~g}$ \\
\hline Upper limit & $3.269 \mathrm{~g}$ & $3.269 \mathrm{~g}$ & $3.27 \mathrm{~g}$ & $3.27 \mathrm{~g}$ & $3.273 \mathrm{~g}$ & $3.269 \mathrm{~g}$ & $3.253 \mathrm{~g}$ & $3.246 \mathrm{~g}$ & $3.234 \mathrm{~g}$ \\
\hline Lower limit & $2.959 \mathrm{~g}$ & $2.959 \mathrm{~g}$ & $2.96 \mathrm{~g}$ & $2.96 \mathrm{~g}$ & $3.002 \mathrm{~g}$ & $2.959 \mathrm{~g}$ & $2.945 \mathrm{~g}$ & $2.938 \mathrm{~g}$ & $2.926 \mathrm{~g}$ \\
\hline
\end{tabular}

The Table 3 shows that there is no ovule that does not meet the requirements because the overall weight of ovule falls within upper and lower limits uniformity of weight.

\section{Disintegration time observations}

Tested were carried out on each formula in the citrate buffer media on conditions that the preparations were completely melted into the media $<60$ minutes. Test results can be seen in Table 4 .

Table 4: disintegration time curcumin ovule

\begin{tabular}{|c|c|c|c|c|c|c|c|c|c|}
\hline $\begin{array}{l}\text { Times } \\
\text { (minutes) }\end{array}$ & F1 & $\mathrm{F} 2$ & F3 & F4 & F5 & F6 & F7 & F8 & F9 \\
\hline $\mathrm{T} 1$ & 45.37 & 42.46 & 38.44 & 33.28 & 28.18 & 24.36 & 21.27 & 18.47 & 15.54 \\
\hline $\mathrm{T} 2$ & 45.41 & 42.55 & 37.51 & 33.14 & 29.23 & 24.17 & 21.44 & 18.41 & 15.57 \\
\hline T3 & 46.18 & 42.38 & 38.28 & 33.32 & 28.33 & 23.49 & 21.38 & 18.38 & 15.51 \\
\hline $\begin{array}{l}\text { Average } \pm \\
\text { SD }\end{array}$ & $\begin{array}{l}46.05 \\
0.456\end{array}$ & $\begin{array}{l}42.46 \\
0.085\end{array}$ & $\begin{array}{ll}38,07 & \pm \\
0.497 & \end{array}$ & $\begin{array}{l}33.24 \\
0.094\end{array}$ & $\begin{array}{ll}28.58 & \pm \\
0.567 & \end{array}$ & $\begin{array}{l}24.00 \\
0.457\end{array}$ & $\begin{array}{l}21.36 \\
0.086\end{array}$ & $\begin{array}{ll}18.42 & \pm \\
0.04 & \end{array}$ & $\begin{array}{l}15.54 \\
0.002\end{array}$ \\
\hline
\end{tabular}


*T1: Treatment 1, T2: Treatment 2, T3: Treatment 3.

\section{Dissolution Tester}

The ovule release test lasted for 600 minutes using a dissolution paddle model with citrate buffer as a medium of $900 \mathrm{ml}$ at $37^{\circ} \mathrm{C}$. The test results can be seen in Fig.4.

Each formula shows a different release, this is because the concentrations of PEG 400 and PEG 6000 base are used in the formulas. Formula 1; 2; 3 ; and 4 with concentration PEG 400 : PEG 6000 (10:90; 20:80; 30:70;40:60) shows poor relase among other formulas, less than $50 \%$ released curcumin within 600 minutes. Formula 5 and 6 begin to show good release because curcumin in released by more than $80 \%$ within 600 minutes. Formula 7 and 8 show a release of more than $80 \%$ within 400 minutes. While formula 9 provide maximum release (more than 90\%) within 300 minutes. All these release are due to the influence of the base used. The higher the base concentration of PEG 400, the faster the drug release in the artificial vaginal fluid medium, because PEG 400 decreases the melting rate of PEG 6000 and the release of curcumin from the ovule preparations ${ }^{9}$. The combination of PEG 400 and PEG 6000 with the right concentration results in good release.

\section{REFERENCES}

1. Abass, H., Kamel, R., and Abdelbary, A. Metronidazole Bioadhesive Vaginal Suppositories : Formulation, In Vitro, and In Vivo Evaluation. International Journal of Pharmacy and Pharmaceutical Sciences. 2012; (4): 44-353.

2. Agoes, G. Development of Pharmaceutical Form. ITB-Press, Bandung. 2008; 337-352

3. Boyonapalli, S. S., dan Kong, T. Curcumin, The King of Spices : Epigenetic Regulatory Mechanisme in The Prevention of Cancer, Neurological, and Inflammatory Diseases. CurrPharmacol Rep. 2015; (1):129-139.

4. Chen, J., Spear S.K., Huddleston J.G., and Rogers, R.D. 2012. Polyethylene Glycol and Solutions of Polyethylene Glycol as Green Reaction Media. Green-Chem. 2005; (7):64-82.

5. DepKes RI. Farmakope Indonesia, $4^{\text {th }}$ Ed. EGC. Jakarta. 1995; 5-7.

6. Hutanu, D., Frishberg, M.D., Guo, L., and Darie, C.C. Recent Applications of Polyethylene Glycols (PEGs) and PEG Derivates. Modern Chemistry and Application. 2014; (2):2.

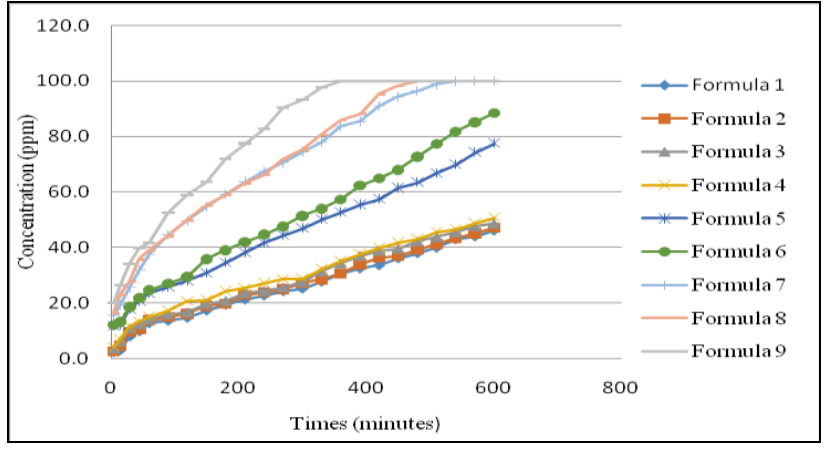

Figure 4: Graph of release the curcumin ovules

\section{CONCLUSIONS}

Curcumin can be formulated into ovule preparations using PEG 400 and PEG 6000 as the base preparations. The results of the charachteristic of the ovule show the whole formula fulfill the preparations conditions. Ovule dissolution testing shows formula 7; 8; and 9 given release of more than $80 \%$ within 400 minutes.

\section{ACKNOWLEDGMENTS}

This research was facilitated by pharmacy faculty Universitas Sumatera Utara.

7. Jayaprakasha, G. K., Rao, L. J., Sakariah, K. K. Antioxidants Activities of Curcumin, Demethoxycurcumin, and Bisdemethoxycurcumin. Food Chem. 2005; (8):720-724.

8. Martien, R., Adhyatmika, Irianto, I. D. K., Farida, V., Sari, D. P. Development of Nanoparticle Technology as a Drug Delivery System. Pharmaceutics Magazine. 2012; (8):1-7.

9. Norvisari, M. The Influence of Basic Combination of PEG 400 and PEG 6000 On Physical and Explanation Properties Mefenamic Acid In Suppositories Preparation. Thesis. 2008; 73-80

10. Shanmugam, S., Kim, Y. H., Park, J. H., Im, H. T., Sohn, Y. T., Yong, C. H. Sildenafil Vaginal Suppositories : Preparations, Characterization, In Vitro and In Vivo Evaluation. Drug development and Industrial Pharmacy. 2013; (1):1-10.

11. Tonnesen, H. H., and Karlsen, J. Studies on Curcumin and Curcuminoid: Alkaline degradation of Curcumin. Lebenum Uniers Forch. 1985; (180):132-134. 